\title{
Intermediary Role Of Nostalgia Tendency In The Effect Of Electronic Word Of Mouth Communication On Tourists' Destination Visit Intentions
}

\author{
Gönül GÖKER \\ Çankırı Karatekin University, Turkey \\ İlknur AYAR \\ Çankırı Karatekin University, Turkey
}

Received: 24 February 2020. Revision received: 31 March 2020. Accepted: 3 April 2020.

\begin{abstract}
This study was aimed to reveal the mediating role of nostalgia tendencies in the effect of E-Wom (Electronic Word of Mouth Communication) on Tourists' intention to visit UNESCO World Heritage City Safranbolu. The authors aimed to reveal the effect of word of mouth communication on the destination preference, as well as to determine whether the nostalgia tendency has an intermediary role during this communication. Survey method was used in the research as the data collection tool. The survey was administered to all travel lovers. A total of 402 people participated in the survey. In this research, the structural equation model was used to determine the mediating role of the nostalgia trend in the impact of E-wom on travel intent. Responses were analyzed with SPSS statistical software. According to the results of the research, E-wom has an impact on travel intention. The partial mediating role of the "nostalgia tendency" in "the effect of e-wom on travel intention" was determined. Comments and suggestions were developed depending on the analysis results obtained at the end of the study.
\end{abstract}

Key Words: electronic word of mouth communication, nostalgia tendency, travel intention, Safranbolu

JEL Classification: L83, M31, Z33

Reference: Goker, G. \& Ayar, I. (2020). Intermediary Role Of Nostalgia Tendency In The Effect Of Electronic Word Of Mouth Communication On Tourists' Destination Visit Intentions. Journal of Tourism and Services, 20(11), 44-59. doi: 10.29036/jots.v11i20.140

\section{Introduction}

E-commerce is one of the most important advantages that developments in information technologies offer to human life (Bartok, 2018: 5-20). Many sectors such as cosmetics, furniture, souvenirs, textile, electronics etc. can now meet their consumers more flexibly, faster and creatively with the e-commerce wave. E-commerce, that is, the activity of shopping in the electronic environment has moved away from being a situation where individuals only pay the price and buy the product. Ecommerce has brought along e-wom, namely electronic word of mouth communication.

Before describing electronic word of mouth communication, it is necessary to slightly dwell on word of mouth communication. Word of mouth communication is people's way of asking each other's opinion about a certain product or brand, in a way that does not involve commercial content (Gülmez, 2010: 316; Chankoson \& Thabhiranrak, 2019: 130). Word of mouth communication is the most reliable method that people adopt in the process of making a purchase decision. E-wom, on the other hand, is the decision-making process of people by examining the comments and criticisms made by other consumers regarding the product and brand. Firms that make sales over the Internet have styles of 


\section{JOURNAL OF TOURISM AND SERVICES}

Issue 20, volume 11, ISSN 1804-5650 (Online)

www.jots.cz

providing services with technical and visual details that will facilitate e-wom and also direct their marketing and competition strategies accordingly such as commenting, liking and rating.

The tourism and travel sectors are also among the main sectors that sell products and services within the scope of e-commerce. The process that started with online reservation is integrated with ewom today. Conveniences such as virtual navigation, comments made by previous visitors and if there is, a scoring system regarding destinations and accommodation businesses reveal e-wom's great influence on individuals' purchase decision processes.

The personal tastes and preferences of individuals who want to experience travel are different from each other. While some potential consumers are interested in natural beauties or summer resorts, some may intend to visit historical and cultural sites (Mura \& Kajzar, 2019: 40-54). Other than the effect of many elements such as family, cultural level, education, income, circle of friends, etc. on individuals' choice of destinations to visit, their psychological tendencies can also be influential. The nostalgia tendency can also play an important role in the preferences of potential consumers as a psychological tendency.

Safranbolu district, $8 \mathrm{~km}$ from Karabük province, takes its name from the "saffron" plant that grows here (Şenol, 2016: 187). North of Turkey, is located in the western Black Sea region. This city, which is an unspoiled example of Turkish urban history, is included in the UNESCO World Heritage List as one of the rare cities that has been declared a protected area with its traditional city texture, wooden masonry houses and monumental structures (Republic of Turkey, Culture And Tourism Ministry, kvmgm.ktb.gov.tr).

In this study, besides measuring the effect of e-wom on tourists' destination visit intention, the mediating role of the nostalgic tendency in this regard was also discussed. In this study, it was aimed to reveal the mediating role of nostalgia tendencies in the effect of e-wom (Electronic Word of Mouth Communication) on tourists' intention to visit UNESCO World Heritage City Safranbolu.

Therefore, 2 questions arise regarding the study:

Question 1: Does E-wom (electronic word of mouth) have an effect on the intention of tourists to visit UNESCO World Heritage City Safranbolu?

Question 2: Is there a mediating role in the nostalgia trend in the effect of tourists on their intention to visit UNESCO World Heritage City Safranbolu?

\section{Conceptual Framework}

\subsection{Nostalgia Tendency}

Nostalgia is a combination of the words "nostos", which means return to the past in Greek, and "algos", which means grief and pain. Nostalgia evokes a longing for the past (Toksar1, Senir and Mürütsoy, 2015: 198 \& Özhan and Altuğ, 2017: 338). The term nostalgia was first derived from a thesis written in the field of medicine by Johannes Hofer in 1688 in order to define the homesickness of the Swiss mercenaries who fought away from their home countries (Özhan and Altuğ, 2017: 338). Nostalgia is a state of emotion, which is a blend of experiences that individuals experience starting from a young age. These experiences have taken place in the memory of individuals in the family, social environment or through the media (Sierra and McQuitty, 2007: 100).

Although nostalgia involves sad and happy moments of the past, negative events are filtered out in the brain, leaving behind only positive, happy moments. For this reason, people always yearn for the past (Shields and Johnson, 2016: 713). Boym defines nostalgia as"a sense of loss and displacement, but also the love relationship that a person establishes with his/her own fantasy." Qtd. in (Bauman, 2018: 10) Nostalgia can also be described as a defense mechanism in the age of accelerated life rhythms and historical turmoil. Stern (1992), on the other hand, explains nostalgia as an emotional state that the 


\section{JOURNAL OF TOURISM AND SERVICES}

Issue 20, volume 11, ISSN 1804-5650 (Online)

www.jots.cz

individual desires in a cleaner state by idealizing past times. Qtd. in (Rodrigues, Kastenholz and Morais, 2012: 75).

Nostalgia is divided into three categories, being true (personal) nostalgia, revived nostalgia, collective (interpersonal) nostalgia. True nostalgia is the manifestation of the experiences that the individual personally experienced. Experience is necessary to experience true nostalgia. For example, a photograph of the person from childhood years, the music s/he listens to or the feelings that manifest when $\mathrm{s} /$ he remembers the moments $\mathrm{s} /$ he lived in a concrete sense. These feelings can arise as longing, pain and happiness. What we describe as secondarily revived nostalgia is actually the person's living that moment without experiencing it and by dreaming it and longing for that moment. Revived nostalgia tells about the periods before the birth of the person. For example, looking at old Turkish movies and longing for the 70 s one has never lived, reading historical books, buying antiques, etc. situations can be shown as examples to this (Eser, 2007: 4-5-6).

Contrary to popular belief, nostalgia tendency is not a situation that occurs in middle age. In today's age of technology, which is called the modern era, individuality increases together with the prevalence of social media, some values that bring socio-cultural development in people are lost and a group of people who are selfish, pragmatist and try to save the moment is formed. These situations experienced by the young people of the age of technology lead them towards the past, which they imagine to be warmer, safe, slow, calm and peaceful. The youth of the modern age, who are subject to the classification of the Z (2000-2020) generation are more inclined to nostalgia unlike previous generations. This shows that they are in emotional states related to finding the upper reality and seeking their own identity, and that in fact they are directed towards a postmodernist perspective. Thirdly, collective (interpersonal) nostalgia is a state of nostalgia peculiar to a culture, nation or a generation. The group of people who have passed through shared life experiences is called a "generation". For example, people born in the late 80s and early 90s have an emotional attachment to the stuff, movies, series, commercials and music of the 90s. That this generation shows an emotional sensitivity to any kind of concrete or abstract event, situation or object that remind them of their childhood and trigger childlike and pure feelings in them can be expressed as "collective nostalgia" (Güzel and Okan, 2016: 139-140 \& Öztürk , 2015: 33-34-35).

In terms of marketing, nostalgia is a personal emotion, which is triggered by consumers' experiences and which affects their current product/service choices (Özhan and Altuğ, 2017: 338). The desire of individuals not to break their ties from the past life may also be reflected in their preferences to purchase products. Products and experiences that will remind them of their own identity or keep their memories fresh can attract individuals. For example, the memory of a sports activity with the family at a young age can encourage them to go to the same activity to experience this feeling again at adult ages (Sierra and McQuitty, 2007: 99-100). In some individuals, this manifests itself with "brand nostalgia" addiction. Loyalty to the brand increases with the brand's associating positive memories about the past life in the individual (Shields and Johnson, 2016: 713; Kmeco et al., 2019: 118-128). Brand loyalty focuses on the positive emotions that arise at the customer and applies them to the product (Zaman and Bogdan, 2019).

Limited study has been found in the literature on nostalgia tendency and travel intention and preference. In their work, Phau, Quintal, Marchegiani, and Lee (2016) investigated how the trend of nostalgia affects Italian travelers' travel attitudes and their intentions to visit tourist destinations, and also explored travel risks perceived as a moderate role in the relationships between personal and historical nostalgia and travel attitudes. The results only showed that personal nostalgia had a positive effect on travel attitudes, which was positively associated with the intention to travel to Italy.

As for Chen, Yeh and Huan (2014), they aimed to determine whether nostalgic feelings affect people's intentions to visit nostalgia-themed restaurants. According to the results of the research, it was observed that the nostalgic feeling affects the intention of consumption both directly and indirectly. For 


\section{JOURNAL OF TOURISM AND SERVICES}

Issue 20, volume 11, ISSN 1804-5650 (Online)

www.jots.cz

a nostalgic restaurant, the nostalgic feeling is the most important component of the restaurant in attracting customers.

\subsection{Electronic Word of Mouth Communication (E-Wom)}

Word of mouth communication (wom) is defined as the form of (positive or negative) verbal communication between communities, constituting potential customer groups such as family, business environment and friend circle (Ennew, Ashish, and Derek, 2000: 78). Word of mouth communication involves consumers' positive or negative comments about a product, brand or service (Turgut, Akyol and Giray, 2016: 60). According to another definition, word of mouth communication means consumers' expressing their experiences about products or services to other people around them positively or negatively (Gülmez, 2011: 30-31). The first definitions of the concept of word of mouth communication were presented by Katz and Lazarsfeld. Katz and Lazarsfeld define word of mouth communication as information sharing among consumers during product marketing (Aydın and Gürbüz, 2019: 26). It can be said that word of mouth communication is the most valuable source of marketers. In the decisionmaking process of individuals, a reliable friend or a family member has a great influence (Buttle and Groege, 2017: 1035; Stverkova et al., 2018: 325; Bacik et al., 2019: 208-220). Sharing with the environment can cause changes in the attitudes and behaviors of individuals regarding products and services (Aydin and Gürbüz, 2019: 26). In word of mouth communication, it is seen that individuals share their experiences with each other and find the information they obtain in this way more reliable (Gülmez, 2011: 31). Consumers with a good brand image, can talk with others as mouth marketers (Maisam and Mahsa, 2016).

The Internet (Özbük and Aksoy, 2017: 84), which has been in our lives for nearly 20 years, is the source of the electronic word of mouth communication (e-wom) (Sarış1k and Özbay, 2012: 3). For example, Amazon.com is one of the first online shopping sites to promote and sell their products on the site since 1995 (Zhang, Ye, Law and Li, 2010: 694). Technological developments have increased the number of consumers seeking information in a virtual environment (Androniceanu, 2019). These developments have shaped the way of word of mouth communication and revealed the electronic form of word of mouth communication (Sar1ssik and Özbay, 2012: 3). Electronic word-of-mouth communication is positive or negative comments made by consumers on the Internet regarding any institution, product, company or brand (Özbük and Aksoy, 2017: 84).

Advances in online marketing technology have allowed manufacturers or retailers to develop some strategies (Kinnunen et al, 2019). The first of these strategies is to publish the information of past sales on the Internet. Another one is sharing information about the firm on social media platforms such as Facebook and inviting consumers to comment and like. Consumers' positive or negative comments are described as e-wom ( $\mathrm{Li}$ and $\mathrm{Wu}, 2018: 1331-1332)$. For example, in an area of Beijing, the capital of the People's Republic of China, only 30,574 restaurants, shopping and entertainment, etc. facilities are registered in dianping.com (Zhang et al., 2010: 695). Unlike traditional wom, in e-wom the information spreads faster and the potential effect of e-wom on customers' decision making processes can be stronger than that of traditional wom (Jeong and Jang, 2011: 356).

\subsection{Travel and Electronic Word of Mouth Communication (E-Wom)}

All the people living in the world are potential customers for the travel and tourism industry. For the travel experience, the consumer must go to the product and therefore there has to be a distribution system. Tourism product distribution differs from other products. Looking at the history of the distribution system in tourism, it was seen that Thomas Cook pioneered this in England in the 1840s (Misirl1, 2015: 40-41). There are many distribution channels such as Travel Agencies, Tour Operators, 


\section{JOURNAL OF TOURISM AND SERVICES}

Issue 20, volume 11, ISSN 1804-5650 (Online)

www.jots.cz

Tour Wholesalers, Private Distribution Channels, Internet, Hotels, Retailers (Mirzayeva, Sarıssı and Ekber, 2016: 24-25, Misirli, 2015: 41) that we can see directly or indirectly in the Tourism and Travel Industry.

It is the Internet that is spreading the fastest and is used the most among the travel industry distribution channels. Customers who make a reservation using the Internet not only get the convenience of making a reservation but also make use of the many opportunities of the Internet.

The developments in information technologies and e-commerce have not only facilitated distribution but also increased the interaction between tourism components and consumers, and paved the way for great opportunities. It provided direct access to web-based travel agencies such as E-bookers and online distribution systems and vertical travel portals (Y1ldiz and Yildız, 2015: 602).

E-wom is shown as the most important source of information in the consumer purchasing decision process. Since abstract and service-based touristic products will be difficult to evaluate before consumption, there are many touristic consumers who benefit from e-wom (Sarış1k and Özbay, 2012: 8). Low cost, product comparison, virtual community building, interaction and 24-hour accessibility (Ho, Lin and Chen, 2012: 1468) and inclusion of more photographs and videos about destinations and hotels compared to traditional travel agencies (Lien, Wen, Huang and Wu, 2015: 210) may be counted among the advantages that searching online travel information provides for consumers. Sites such as Tripadvisor provide unbiased information about hotels, touristic places and restaurants around the world. There are millions of unbiased reviews on Tripadvisor. The increase in such electronic interactions between individuals enables marketers to see this as an advantage for them and paves the way for developing online marketing strategies (Litvin, Goldsmith and Pan, 2008: 458).

There are studies in the literature aimed at explaining the relationship between travel preference and e-wom. For example, Doosti, Jalilvand, Asadi, KhazaeiPool, and MehraniAdl (2016) investigated how electronic word-of-mouth communication (e-WOM), affect attitude, city image and the intention of tourists to visit a touristic city. The results obtained in the study showed that e-WOM has a positive and significant effect on the attitude of the tourists and the overall city image. In addition, e-WOM, attitude towards the city and the overall city image have been important determinants in tourist intentions.

Grewal, Cline and Davies (2003) found that WOM messages affect the purchaser's intentions and thoughts.

In their studies examining tour behavior among foreign students in Malaysia, Krishnapillai and Ying (2017) discovered a positive and meaningful effect of e-wom on students' intention to travel.

The findings obtained from the studies of Chen, Shang and Li (2014), which aimed at revealing how travel blogs as a tool of e-wom can effect a tourist's future behavioral intent, revealed that the blog can be used as an important tool for tourism marketing. In this context, the authors stated that new, reliable and interesting information about the destination can persuade tourists to visit a destination.

\section{Methodology}

The following model was developed to determine the mediating role of the nostalgia tendency in the relationship between electronic word-of-mouth communication and travel intention. Three different relationships were foreseen in the model to reveal its mediating effect. The first is the relationship between electronic word of mouth communication and travel intention; the second is the relationship between word of mouth communication and nostalgia tendency; and the third is the relationship between nostalgia tendency and travel intention.

Research hypotheses are shown on the model in Figure 1.

H1: Electronic word of mouth communication positively affects travel intent.

H2: Electronic word of mouth communication positively affects the nostalgia tendency.

H3: Nostalgia tendency positively affects the intention to travel. 


\section{JOURNAL OF TOURISM AND SERVICES}

Issue 20, volume 11, ISSN 1804-5650 (Online)

www.jots.cz

H4: The nostalgia tendency has an intermediary role in the relationship between electronic word of mouth communication and travel preference.

Figure 1. Research Model

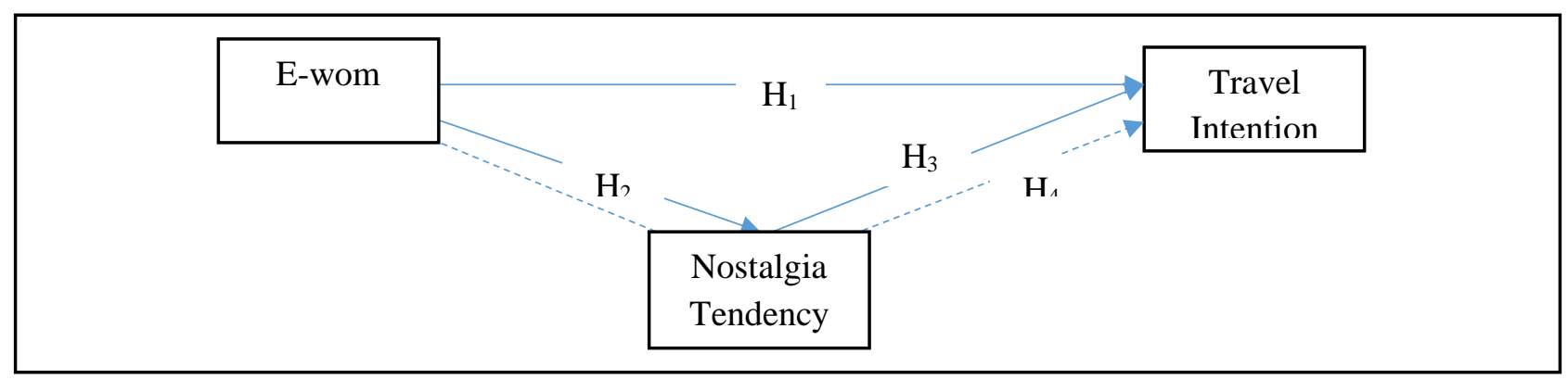

Source: Authors' processing

The universe of the research consisted of potential local tourists who would participate in the domestic tourism movements. The survey was conducted between September and December 2019. Considering the time constraint, random sampling method was used to obtain a sufficient sample size with valid response in the study. According to Saunders, Lewis and Thornhill (2009: 219), the number of samples required to get accurate results in 95\% reliability range in populations over 100,000 is 384 people. 402 of the questionnaires applied in accordance with this rule were included in the study. The research survey was applied to online travel blogs, social media travel groups, travel forums, mobile travel applications as well as travel lovers. The data collected were analyzed using statistical methods and structural equation model was utilized. All analyzes made in this article were made by applying Amos SPSS Version 22, a statistical software. Statistical package programs, which enable the application of structural equation model, were used.Significance level was accepted as $5 \%$. The null hypothesis of the research is as follows:

Null hypotheses: The nostalgia tendency does not play an intermediary role in the relationship between electronic mouth-to-mouth communication and travel preference.

The primary data of the study were collected by applying the Electronic Word of Mouth Communication Scale, Nostalgia Tendency Scale and Travel Intention Scale face to face and online. The electronic word of mouth communication scale used in the research was developed by Jalilvand and Samiei (2012). This scale consists of 6 items. The nostalgia tendency scale was adapted from the work of Baker and Kennedy (1994) by Hung-Bin Chen, Yeh and Huan (2014) and consists of 8 items. Finally, a 3-item scale developed by Kassem et al. (2010) and adapted by Jalilvand, Ebrahimi and Samiei (2013) was used to measure the intention to travel. All of these scales are of Likert type and have values between Strongly Disagree (1) and Strongly Agree (7). A section, in which there are some questions aimed at obtaining the socio-demographic information of the participants such as age, gender and education level was also included.

The data collected were analyzed by statistical methods and structural equation model was used. Structural equation modeling offers great potential for theory development and structure validation in psychology and social sciences (Anderson and Gerbing, 1988). A structural model indicates the causal relationships of structures with each other. Also, the sobel test was used to measure whether the intermediate variable is important. The Sobel test is used to determine if a decrease in the relationship between the dependent and independent variable is observed after adding the intermediate variable (Yilmaz and Dalbudak, 2018: 522; Derevianko, 2019: 519-520). 


\section{JOURNAL OF TOURISM AND SERVICES}

Issue 20, volume 11, ISSN 1804-5650 (Online)

www.jots.cz

In order to test the construct validity of the scales used, single factor confirmatory factor analysis was performed. The fit values of the measurement models for testing the validity of the scales are shown in Table 1.

Table 1 Fit Values of the Scales

\begin{tabular}{|l|c|c|c|c|c|c|}
\hline Scale & $\mathbf{X}^{\mathbf{2}}$ & $\mathbf{d f}$ & $\mathbf{X}^{\mathbf{2}} \mathbf{\text { df }}$ & $\mathbf{G F I}$ & $\mathbf{C F I}$ & RMSEA \\
\hline e-wom & 23,431 & 8 & 2,929 &, 98 &, 99 &, 069 \\
\hline Nostalgia Tendency & 55,882 & 19 & 2,941 &, 96 &, 96 &, 070 \\
\hline Travel Intention & 3,018 & 1 & 3,018 &, 99 &, 99 &, 071 \\
\hline Good Fit Values * & & & $\leq \mathbf{3}$ & $\mathbf{2 0 , 9 0}$ & $\mathbf{\geq 0 , 9 7}$ & $\leq \mathbf{0 , 0 5}$ \\
\hline $\begin{array}{l}\text { Acceptable Fit } \\
\text { Values* }\end{array}$ & & & $\leq \mathbf{4 - 5}$ & $\mathbf{0 , 8 9 - 0 , 8 5}$ & $\mathbf{\geq 0 , 9 5}$ & $\mathbf{0 , 0 6 - 0 , 0 8}$ \\
\hline
\end{tabular}

* Source: Meydan and Şeşen, 2011: 37 p>.05, X2 = Chi-Square (Chi-Square); df = Degree of Freedom; GFI = Goodness Of Fit Index; CFI = Comparative Fit Index; RMSEA = Root Mean Square Error of Approximation (Approximate Square Root of Errors)

Source: Authors' processing

Since the values in Table 1 were within acceptable limits, the single-factor structures of the scales were confirmed. In addition, confirmatory factor analysis (CFA) was used as a measurement model to examine e-wom, nostalgia tendency and travel intent. CFA results show that goodness of fit is acceptable $\left(\chi^{2}=281.547, \chi^{2} /\right.$ dfratio $\left.2.448, p=0.000\right)$, the GFI value 0.923 , RMSEA value 0.06 , and CFI value 0.95 confirm the acceptable goodness of fit of the model (Schermelleh-Engel, Moosbrugger and Müller, 2003). To assess the convergent validity of the measurements, Fornell and Larcker (1981) recommend measuring compound reliability (CR> 0.70) and the mean variance (AVE $>0.50)$ to be obtained for each construct. Table 2 shows the acceptable minimum CR and AVE levels of all variables.

Table 2 Cronbach's Alpha and AVE-CR values of the factors

\begin{tabular}{|c|c|c|c|c|c|}
\hline Variable & Item & Factor loading & $\begin{array}{l}\text { Cronbach's } \\
\text { Alpha }\end{array}$ & CR & AVE \\
\hline \multirow[t]{8}{*}{ Nostalgia Tendency } & Nos1 &, 56 & \multirow[t]{8}{*}{0,85} & \multirow[t]{8}{*}{0,861} & \multirow[t]{8}{*}{0,44} \\
\hline & Nos2 &, 78 & & & \\
\hline & Nos3 & ,67 & & & \\
\hline & Nos4 &, 71 & & & \\
\hline & Nos5 &, 68 & & & \\
\hline & Nos6 &, 54 & & & \\
\hline & Nos7 & 60 & & & \\
\hline & Nos8 & 74 & & & \\
\hline \multirow[t]{6}{*}{ e-Wom } & e-Wom1 & 86 & \multirow[t]{6}{*}{0,89} & \multirow[t]{6}{*}{0,889} & \multirow[t]{6}{*}{0,58} \\
\hline & e-Wom2 & 87 & & & \\
\hline & e-Wom3 & 87 & & & \\
\hline & e-Wom4 & 78 & & & \\
\hline & e-Wom5 &, 50 & & & \\
\hline & e-Wom6 & 61 & & & \\
\hline \multirow[t]{3}{*}{ Travel Intention } & Trav1 & 83 & \multirow[t]{3}{*}{0,77} & \multirow[t]{3}{*}{0,796} & \multirow[t]{3}{*}{0,57} \\
\hline & Trav2 &, 58 & & & \\
\hline & Trav3 & 83 & & & \\
\hline
\end{tabular}

Since the DFA model gave good fit values, Croanbach's $\alpha$, Average Variance Extracted-AVE and Composite Reliability-CR values of each structure were examined separately. As can be seen, Croanbach's 


\section{JOURNAL OF TOURISM AND SERVICES}

Issue 20, volume 11, ISSN 1804-5650 (Online)

www.jots.cz

$\alpha$ and CR values are above the critical value of 0.70 (Hair et al., 2009) and are acceptable. The AVE value (0.44) of the nostalgia tendency structure is below the critical value of 0.50 . However, if other criteria are met, values slightly below 0.5 can also be accepted (Fornell \& Larcker, 1981). Hair et al. (2009) stated that for combination validity, AVE value should be greater than 0.5 and CR ratio should be greater than AVE (CR> AVE; AVE> 0.5). When the structures in question are evaluated, it is seen that the CR value in each structure is higher in the AVE value. Discriminant validity was tested after combination validity.

Table 3 Correlations between Factors as a Result of CFA, Compound Reliability (CR) and AVE Values (square roots of AVE values

\begin{tabular}{|c|c|c|c|c|c|}
\hline Variables & $\mathrm{CR}$ & AVE & NOS & E-WOM & TRAV \\
\hline NOS & 0,86 & 0,44 & $0,66^{a}$ & & \\
\hline E-WOM & 0,88 & 0,58 & 0,27 & $0,76^{a}$ & \\
\hline TRAV & 0,79 & 0,57 & 0,58 & 0,38 & $0,75^{\mathrm{a}}$ \\
\hline
\end{tabular}

Source: Authors' processing

The requirement for discriminant validity is that the square root value of AVE of a latent variable is greater than the correlation values of that variable with other variables (Fornell and Larcker, 1981: 4546; Hair et al., 1998: 612). When the square root values of AVE in Table 3 and the correlations between variables were examined, it was determined that the discriminant validity was also provided for all latent structures.

The data regarding the demographic information of the participants are given in Table 4.

Table 4 Demographic Information

\begin{tabular}{|l|c|c|}
\hline Measure & Frequency & $\mathbf{\%}$ \\
\hline Gender & 189 & 47,0 \\
\hline Male & 213 & 53,0 \\
\hline Woman & & \\
\hline Age & 44 & 10,9 \\
\hline-20 & 149 & 37,1 \\
\hline $21-30$ & 133 & 33,1 \\
\hline $31-40$ & 53 & 13,2 \\
\hline $41-50$ & 20 & 5,0 \\
\hline $51-60$ & 3 &, 7 \\
\hline $60-$ & & \\
\hline Marital Status & 219 & 54,5 \\
\hline Single & 183 & 45,5 \\
\hline Married & & \\
\hline Education Status & 10 & 2,5 \\
\hline Primary education & 28 & 7,0 \\
\hline High school & 74 & 18,4 \\
\hline Associate & 182 & 45,3 \\
\hline License & 108 & 26,9 \\
\hline Graduate & Source: Authors' processing & \\
\hline
\end{tabular}




\section{JOURNAL OF TOURISM AND SERVICES}

Issue 20, volume 11, ISSN 1804-5650 (Online)

www.jots.cz

The gender ratios of the participants in the research are close to each other. 70 percent of the participants were between 21-41 years of age, and answers were received from a very young population. Again, it was found that more than $70 \%$ of the participants had undergraduate and graduate education.

\section{Results}

After this stage, three-stage regression analysis proposed by Baron and Kenny (1986) was carried out to explain the effect of electronic word of mouth communication on travel preference and the mediating role of the nostalgia tendency in this effect. According to this method, the independent variable must have an effect on the dependent variable and the mediating variable. When the mediating variable is included in the regression analysis together with the independent variable, the regression coefficient of the independent variable on the dependent variable must decrease whereas the significant effect of the mediating variable on the dependent variable must continue.

To test the relationship, the first structural model was run to measure the effect of the independent variable on the dependent variable. The results gave good goodness of fit values. $(\chi 2=$ 49,079, $\chi^{2} /$ dfratio 1.963, $\mathrm{p}=0.003$ ), the GFI value 0.974 , RMSEA value 0.04 , and CFI value 0.988 indicate that the model is satisfactory (Schermelleh-Engel, Moosbrugger and Müller, 2003). Figure 2 and Table 5 show the relationship between E-WOM and Travel intention $(\mathrm{p}=0.000)$.

Figure 2 Model 1 Test Results

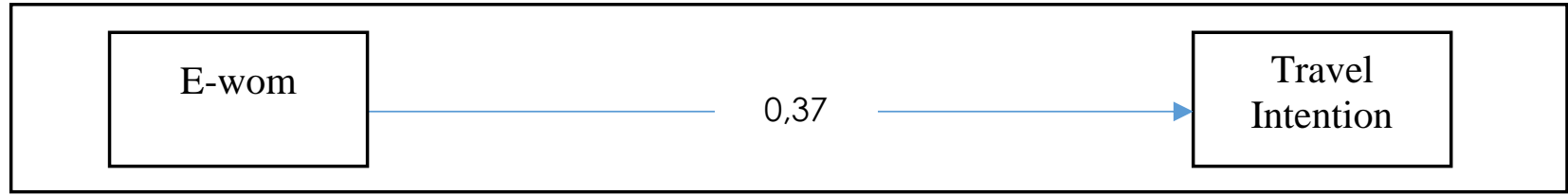

Source: Authors' processing

Standardized beta, standard error and significance values of the routes leading to travel intent from the e-wom variable are shown in Table-5. As shown in Table 5, when Model I was tested, the relationship established between the intention to travel and e-wom $(\beta=.37, \mathrm{p}<.01)$ was found to be significant.

Table 5 Model 1 Hypothesis Test Results

\begin{tabular}{|l|l|l|l|}
\hline Yol & Standardize $\beta$ & Standart Hata & P \\
\hline E-wom $\longrightarrow$ Travel Intention & 0,37 & 0,050 & $* * *$ \\
\hline
\end{tabular}

Figure 3 Model 2 Test Results

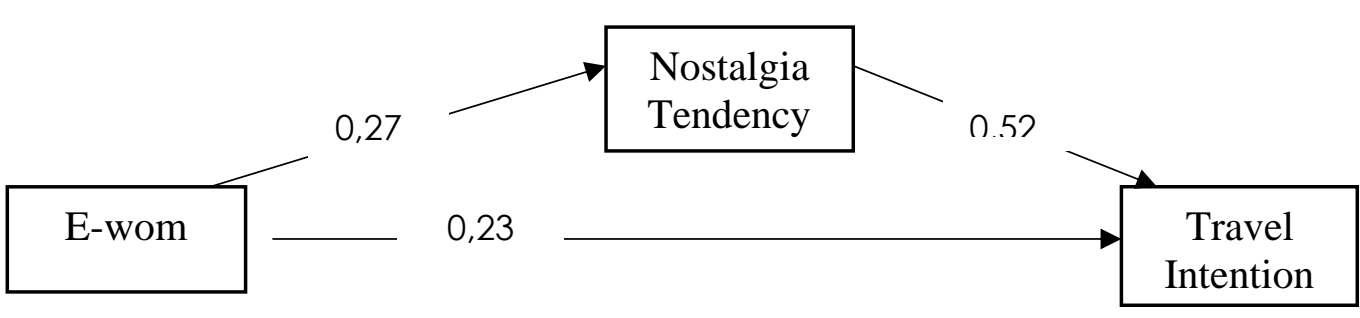




\section{JOURNAL OF TOURISM AND SERVICES}

Issue 20, volume 11, ISSN 1804-5650 (Online)

www.jots.cz

Source: Authors' processing

In the second model, the existence of the second and third effects specified by Baron and Kenny were investigated. Travel intention was accepted as dependent variable, e-wom as independent variable and nostalgia tendency variable as mediating variable. The fit indices obtained by testing the model shown in Figure 3 show that the model is within acceptable limits $\left(\chi^{2}=280.183, \chi^{2} /\right.$ dfratio 2.458, $\left.p=0.000\right)$, the GFI value is 0.923 , RMSEA value 0.06 , and CFI value 0.951$)$.

In the relevant model, the three requirements necessary for the mediation effect are provided. When the model II provided in Figure 3 was tested, when the mediating role of the nostalgia tendency variable in the structure between e-wom and travel intention variable was tested, the relationships established between e-wom and nostalgia tendency $(\beta=.44, \mathrm{p}<.01)$, nostalgia tendency and intention to travel $(\beta=.57 / p<.01)$ were found to be statistically significant. Therefore, H1, H2 and H3 hypotheses were accepted. The relationship between e-wom and intention to travel $(\beta=.04, p<.05)$ continues with the inclusion of the variable of nostalgia tendency in the model. However, after the "nostalgia trend" was included in the model as a mediating variable, it is understood that the standard coefficient between "ewom" and "travel intention" decreased (0.37) compared to the direct model (0.23). According to Baron and Kenny (1986), when the mediating variable is included in the regression analysis together with the independent variable, the regression coefficient of the independent variable on the dependent variable must decrease whereas the significant effect of the mediating variable on the dependent variable must continue. In this case, the "nostalgia tendency" has a partial mediating role in "the influence of e-wom on travel intention". Sobel test was applied to determine the significance of this partial mediation effect. In statistics, the Sobel test tests whether the decrease of the effect in the independent variable is significant after the mediating variable is added to the model and the significance of the mediation effect (Yllmaz and Dalbudak, 2018: 522). As a result of the Sobel test, it was determined that the partial mediation effect was significant at the level of $\mathrm{p}<0.01$ and that the $Z$ statistics was realized as $Z=4.177$. Therefore, $\mathrm{H} 4$ hypothesis was accepted. The standardized beta, standard error and significance values of the routes specified in the model shown in Figure- 3 are shown in Table- 6.

Table 6 Model 2 Hypothesis Test Results

\begin{tabular}{|l|l|l|l|l|l|}
\hline Yol & & & Standardize $\beta$ & Standart Hata & P \\
\hline E-wom & $\rightarrow$ & Nostalji Eğilimi & 0,27 & & \\
\hline E-wom & $\rightarrow$ & Seyahat Niyeti & 0,23 & 0,034 & $* * *$ \\
\hline Travel Intention & $\rightarrow$ & Seyahat Niyeti & 0,51 & 0,045 & $* * *$ \\
\hline
\end{tabular}

\section{Discussion}

According to the results of the analysis, it was seen that E-wom has a positive effect on the travel intentions of people. The results of the research support the previous studies in the literature (Doosti et al., 2016; Krishnapillai and Ying, 2017). When the effect of nostalgia tendency on travel intention was examined, a positive result was obtained. It was observed that the nostalgic tendency has a positive effect on people's travel intentions. These results are supported by a limited number of research results available in the literature (Phau, Quintal, Marchegiani and Lee, 2016; Chen, Yeh and Huan, 2014; Akgün, Şentürk, Keskin and Önal, 2019). Finally, the partial mediating role of the "nostalgia tendency" in "the effect of e- 


\section{JOURNAL OF TOURISM AND SERVICES}

Issue 20, volume 11, ISSN 1804-5650 (Online)

www.jots.cz

wom on travel intention" was determined. No study aimed at determining the mediating role of the nostalgia tendency in e-wom's effect on travel intention was found in the literature. This situation reveals the importance of the research in terms of its contribution to the literature.

Safranbolu, which was included in the UNESCO World Heritage List in 1994, presents architectural examples that reflect the past, culture, economy, technology and way of life of the 18th and 19th century Turkish society. The city, which has hosted many civilizations in its 3000-year history, has significant cultural riches (Çakmak and Kök, 2012). Safranbolu has symbols that remind tourists of their past and culture. In this respect, the findings obtained from the research results are significant in that the nostalgia tendency affects the travel intent of the tourists.

The measurement of the nostalgia tendency, which is the tendency of the individual to experience nostalgic emotions, will allow researchers to better define the consumer market segments based on emotionality. Considering these results, it may be beneficial in terms of marketing and competition for touristic enterprises (hotels, restaurants, cafes etc.) to create business designs and presentations that will touch the nostalgic tendencies of the customers. Local administrations of touristic destinations can benefit from nostalgic items in their promotional and advertising works. Travel lovers may be advised to turn to marketing practices that appeal to their nostalgic feelings.

\section{Conclusion}

In this study, it was aimed to reveal the mediating role of nostalgia tendencies in the effect of EWom (Electronic Word of Mouth Communication) on tourists' intention to visit UNESCO World Heritage City Safranbolu. At the end of the research, it was aimed to reveal the effect of word of mouth communication on the destination preference, as well as to determine whether the nostalgia tendency has a mediating role during this communication.

In line with the developed hypotheses, field research was conducted and an analysis was performed with the data obtained.. For this purpose, a questionnaire was applied to potential local tourists who will participate in domestic tourism movements. 402 of the questionnaires applied were included in the study.

As stated in the findings section, E-wom positively and significantly affected travel intent (H1). Today, potential tourists make more informed choices. They tend to take precautions against possible surprises and demand detailed information about the region to visit or the business to stay. In addition, tourists transfer their travel experiences and knowledge to potential tourists on the Internet.

Electronic word of mouth communication positively affects the nostalgia tendency (H2). Tourist information sharing through E-wom communication affects potential tourists' feelings of nostalgia. For example, sharing photos that evoke people's longing for the past activates feelings of nostalgia. The tendency towards nostalgia, which is activated, positively affects the intention to travel. Nostalgia tendency positively affects the intention to travel (H3).

The nostalgia tendency has an intermediary role in the relationship between electronic word of mouth communication and travel preference $(\mathrm{H} 4)$. While the sharing of travel experiences of tourists on the internet affects the travel intent of potential tourists, nostalgia trends mediate this effect. Namely, experiential sharing on the internet activates the feeling of nostalgia. The sense of nostalgia affects the intention to travel.

This research was conducted to measure the intention to visit Safranbolu, a city with nostalgic feelings. In this respect, the area of research is limited. Future research can be carried out in a wider area with more participants. In addition, the research was carried out with potential tourists. This research can be repeated with the tourists who have visited before. A comparison can be made between potential tourists and previously visited tourists. In addition, the researches to be conducted include experimental methods; will also contribute to the results. 


\section{JOURNAL OF TOURISM AND SERVICES}

Issue 20, volume 11, ISSN 1804-5650 (Online)

www.jots.cz

\section{References}

1. Akgün, A. E., Senturk, H. A., Keskin, H., \& Onal, I. (2019). The relationships among nostalgic emotion, destination images and tourist behaviors: An empirical study of Istanbul. Journal of Destination Marketing \& Management, 100355. https://doi.org/10.1016/j.jdmm.2019.03.009

2. Anderson, J. C. \& Gerbing, D. W. (1988) Structural Equation Modeling In Practice: A Review and Recommended Two-Step Approach, Psychological Bulletin, 103(3), 411-423 https://doi.org/10.1037/0033-2909.103.3.411

3. Androniceanu A. (2019). Collaborative digital economy, main attributes, and challenges. In: Peters M. (eds) Encyclopedia of Educational Philosophy and Theory. Singapore: Springer Nature Singapore Pte Ltd. https://doi.org/10.1007/978-981-287-532-7

4. Aydın, B. O. \& Gürbüz, S. (2019) Sosyal Medya Kullanımının Kurum Çalışanlarının Olumlu Elektronik Ağızdan Ağıza İletişimine Etkisinin Yol Analizi ile İncelenmesi: Aile ve Sosyal Politikalar Bakanlığında Bir Uygulama, Selçuk İetişim Dergisi, 12(1), 22-41. https://doi.org/10.18094/josc.457683

5. Bacik, R., Kmeco, L., Richard, F., Olearova, M., \& Rigelsky, M. (2019). Marketing Instrument of Improving Hotel Management Service: Evidence of Visegrad Group Countries. Marketing and Management of Innovations, 208-220. https://doi.org/10.21272/mmi.2019.1-17

6. Baker, S. M., \& Kennedy, P. F. (1994). Death by nostalgia: A diagnosis of context-specific cases. Advances in Consumer Research, 21, 169-174.

7. Baron, R.M. \& Kenny, D.A. (1986). The Moderator-Mediator Variable Distinction in Social Psychological Research: Conceptual, Strategic and Statistical Considerations, Journal of Personality and Social Psychology, 51(6), 1173-1182. https://doi.org/10.1037/0022-3514.51.6.1173

8. Bartok, O. (2018). The Use of CSR in E-Commerce as a Way to Compete. Journal of Competitiveness, 10(4), 5-20. https://doi.org/10.7441/joc.2018.04.01

9. Bauman, Z. (2018) Retrotopya, Çevirmen: Ali Karatay, 2. Baskı, Sel Yayınc1lık, İstanbul.

10. Buttle, F. \& Groeger, L. (2017) Who Says What To Whom İn What Channel? A Rules Theoretic Perspective On Word-Of-Mouth Marketing, Journal Of Marketing Management, (33)1314, 1035-1059. https://doi.org/10.1080/0267257X.2017.1325390

11. Chankoson, T., Thabhiranrak, T. (2019). The moderating role of brand awareness between the relationship of emotional attachment, brand relationship and positive word of mouth. Polish Journal of Management Studies, 20(1), 129-138. https://doi.org/10.17512/pjms.2019.20.1.11

12. Chen, H. B. \& Yeh, S. S. \& Huan, T.C. (2014). Nostalgic emotion, experiential value, brand image, and consumption intentions of customers of nostalgic-themed restaurants. Journal of Business Research. 67. 354-360. https://doi.org/10.1016/j.jbusres.2013.01.003

13. Chen, Y. C., Shang, R. A., \& Li, M. J. (2014). The effects of perceived relevance of travel blogs' content on the behavioral intention to visit a tourist destination. Computers in Human Behavior, 30, 787-799. https://doi.org/10.1016/j.chb.2013.05.019

14. Çakmak, A. Ç. \& Kök, İ. T. (2012). Destinasyon pazarlaması ve Safranbolu'nun destinasyon imajının ölçülmesi. Ticaret ve Turiz̧m Eğitim Fakültesi Dergisi, (2), 80-101 


\section{JOURNAL OF TOURISM AND SERVICES}

Issue 20, volume 11, ISSN 1804-5650 (Online)

www.jots.cz

15. Derevianko, O. (2019). Reputation stability vs anti-crisis sustainability: under what circumstances will innovations, media activities and CSR be in higher demand?. Oeconomia Copernicana, 10(3), 511-536. https://doi.org/10.24136/oc.2019.025

16. Doosti, S., Jalilvand, M. R., Asadi, A., Khazaei Pool, J., \& MehraniAdl, P. (2016) Analyzing The Influence Of Electronic Word Of Mouth On Visit İntention: The Mediating Role Of Tourists' Attitude And City İmage, International Journal of Tourism Cities, 2, 137-148. https://doi.org/10.1108/IJTC-12-2015-0031

17. Ennew, C. T., Ashish K. B., \& Derek L. (2000). Managing Word of Mouth Communication: Empirical Evidence From India, International Journal Of Bank Marketing, 18(2), 75- 83. https://doi.org/10.1108/02652320010322985

18. Fornell, C., \& Larcker, D. F. (1981) Evaluating Structural Equation Models with Unobservable Variables and Measurement Error, Journal of Marketing Research, 18(1), 39-50.

19. Grewal, R., Cline, T.W., \& Davies, A. (2003) Early-entrant advantages,word-of mouth communication, brand similarity, and the consumer'sdecision-making process. Journal of Consumer Psychology 13 (3), 187-197. https://doi.org/10.1207/S15327663JCP1303 01

20. Gülmez, M. (2010). Ağızdan Ağıza İletişim ve Pazarlama, Ed.Varinli ve Çatı, Güncel Pazarlama Yaklaşımlarnndan Seçeler, Detay Yayıncılık, Ankara.

21. Gülmez, M. (2011) İnternet Üzerinde Ağızdan Ağıza Pazarlama Uygulama Örnekleri, Internet Uygulamalar ve Yönetimi Dergisi, 2 (1), 29-36.

22. Güzel, E., \& Okan, E. Y. (2016) Nostaljiye Genç Bakış: Nostalji İçerikli Reklamların Postmodern Bireyler Üzerindeki Etkisi, Business and Economics Research Journal, 7(3), 137-154. https://doi.org/10.20409/berj.2016321813

23. Hair, J. F., Rolph E. A., Ronald L. T., \& William C. B. (1998) Multivariate Data Analysis, 5th Edition, Prentice-Hall Inc., New Jersey.

24. Hair, J. F., Black, W. C., Babin, B. J., \& Anderson, R. E. (2009). Multivariate data analysis. Upper Saddle River, NJ: Prentice Hall

25. Ho, C. L., Lin. M. H., \& Chen, H. M. (2012) Web Users' Behavioural Patterns of Tourism Information Search: From Online to Offline, Tourism Management, 33, 1468-1482. https://doi.org/10.1016/j.tourman.2012.01.016

26. Jalilvand, M. R. \& Samiei, N. (2012), The impact of electronic word of mouth on a tourism destination choice: Testing the theory of planned behavior (TBP), Internet Research, 22 (5), 591612. https://doi.org/10.1108/10662241211271563

27. Jalilvand, M. R., Ebrahimi, A., \& Samiei, N. (2013). Electronic word of mouth effects on tourists' attitudes toward islamic destinations and travel intention: An empirical study in iran. Procedia Social and Behavioral Sciences, 81(0), 484-489. http://dx.doi.org/10.1016/j.sbspro.2013.06.465

28. Jeong, E., \& Jang, S. (2011) Restaurant Experiences Triggering Positive Electronic Word-OfMouth (Ewom) Motivations, International Journal of Hospitality Management, 30, 356-366. https://doi.org/10.1016/i.ijhm.2010.08.005

29. Kassem, N. O., Lee, J. W., Modeste, N. N., \& Johnston, P. K. (2010), Understanding soft drink consumption among female adolescents using the theory of planned behavior, Health Education Research, 18(3), 278-291. https://doi.org/10.1093/her/cyf017 


\section{JOURNAL OF TOURISM AND SERVICES}

Issue 20, volume 11, ISSN 1804-5650 (Online)

www.jots.cz

30. Kinnunen, J., Androniceanu, A, Georgescu, I. (2019). The role of economic and political features in classification of countries in transition by Human Development Index. Informatica Economică, 23(4), 26-40. https://dx.doi.org/10.12948/issn14531305/23.4.2019.03

31. Kmeco, L., Mezulanik, J., Kascakova, A., \& Civelek, M. (2019). Factors of Demand for Cultural Events in Tourism: the Case of the Czech Republic. Marketing and Management of Innovations, (4), 118-128. https://doi.org/10.21272/mmi.2019.4-10

32. Krishnapillai, G., \& Ying, K. S. (2017). The influence of E-WOM on travel intention among foreign students in Malaysia: Does gender really matter? International Review of Management and Marketing, 7(1), 475-483.

33. Li, X., \& Wu, L. (2018). Herding and social media word of mouth evidence from groupon, MIS Quarterly, 42(4), 1331-1351. https://doi.org/10.25300/MISQ/2018/14108

34. Lien, C. H., Wen, M. J., Huang, L. C., \& Wu, K. L. (2015) Online Hotel Booking: The Effects Of Brand İmage, Price, Trust And Value On Purchase İntentions, Asia Pacific Management Review, 20, 210-218. https://doi.org/10.1016/i.apmrv.2015.03.005

35. Litvin, S. W., Goldsmith, R. E., \& Pan, B. (2008) Electronic Word-Of-Mouth İn Hospitality And Tourism Management, Tourism Management, 29, 458-468. https://doi.org/10.1016/i.tourman.2007.05.011

36. Maisam, S., \& Mahsa, R. D. (2016). Positive Word-of -Mouth Marketing: Explaining the role of value congruity and brand love. Journal of Competitiveness, 8(1), 19-37. https://doi.org/10.7441/joc.2016.01.02

37. Meydan C. H., \& Şeşen H., (2011) Yapısal Eşitlik. Modellemesi AMOS Uygulamalar. Detay Yayıncılık, Ankara.

38. Misırlı, İ. (2015). Seyahat Acentacılı̆ğ ve Tur Operatörlï̈̆̈̈, 5. Bask1, Detay Yayıncilık: Ankara.

39. Mirzayeva, G., Sarışı, M., \& Ekber, Ş. (2016) Otel İşletmelerinin Dağıtım Kanalları Seçimindeki Davranışları: Bakü'deki Otel İşletmelerinde Bir Araştırma, ASSAM Uluslararası Hakemli Dergi, 6, 21-32.

40. Mura, L., Kajzar, P. (2019). Small Businesses in Cultural Tourism in a Central European Country. Journal of Tourism and Services, 10 (19), 40-54. https://doi.org/10.29036/jots.v10i19.110

41. Özbük, M. Y., \& Aksoy, Ş. (2017). Elektronik ağızdan ağıza iletişimin pazarlama literatüründeki önemi, Akdeniz I.I.B.F. Dergisi, (35), 81-100. https://doi.org/10.25294/auiibfd.322648

42. Özhan, Ş., \& Altuğ, N. (2017). Nostalji eğilimi ölçeğinin Türkçe'ye uyarlanması, geçerlilik ve güvenilirlilik çalışmas1, Social Sciences Research Journal, 6(3), 53-66.

43. Öztürk, T. A. (2015) Postmodernizmin Zaman Alg1s1:"Müzikte Nostalji Modası", Medeniyet Sanat, IMÜ Sanat ve Tasarm Fakültesi Dergisi, 1, 31-42.

44. Phau, I., Quintal, V., Marchegiani, C., \& Lee, S. (2016) Looking Beyond Pasta And Pizzas: Examining Personal And Historical Nostalgia As Travel Motive, International Journal of Culture, Tourism and Hospitality Research, 10 (3), 296-309. . https://doi.org/10.1108/IJCTHR-07-2015-0073

45. Rodrigues, Ă., Kastenholz, E., \& Morais, D. (2012). Travel Constraints And Nostalgia As Determinants Of Cross-Atlantic Legacy Tourism, (Ed. Pechlaner, H., Lee, T. J. ve Bò, G. D.) New Minorities and Tourism, İtalya: Eurac Research.

46. Safranbolu, Republic of Turkey, Culture And Tourism Ministry, https://kvmgm.ktb.gov.tr/TR$\underline{44426 / \text { safranbolu-sehri-karabuk.html }}$ 


\section{JOURNAL OF TOURISM AND SERVICES}

Issue 20, volume 11, ISSN 1804-5650 (Online)

www.jots.cz

47. Sarışık, M., \& Özbay, G. (2012). Elektronik ağıdan ağıza iletişim ve turizm endüstrisindeki uygulamalara ilişkin bir yazın incelemesi, Uluslararası Yönetim İktisat ve İsletme Dergisi, 8(16), 1-22.

48. Saunders, M., Lewis, P., \& Thornhill, A. (2009) Research Methods for Business Students. Pearson, New York.

49. Schermelleh-Engel, K., Moosbrugger, H., \& Müller, H. (2003). Evaluating The Fit Of Structural Equation Models: Test Of Significance And Descriptive Goodness Of Fit Measures. Methods Of Psychological Research Online, 8 (2), 23-74

50. Shields, A., \& Johnson, J. W. (2016) What Did You Do to My Brand? The Moderating Effect of Brand Nostalgia on Consumer Responses to Changes in a Brand, Psychology \& Marketing, 33(9): 713-728. https://doi.org/10.1002/mar.20912

51. Sierra, J.J., \& McQuitty, S. (2007) Attitudes and Emotions as Determinants of Nostalgia Purchases: An Application of Social Identity Theory. Journal of Marketing Theory and Practice, 15, 99-112. https://doi.org/10.2753/MTP1069-6679150201

52. Stverkova, H., Pohludka, M., Kurowska-Pysz, J., Szczepańska-Woszczyna, K. (2018). CrossBorder Enterprepreneurship in Euroregion Beskydy. Polish Journal of Management Studies, 18(2), 324-337. https://doi.org/10.17512/pjms.2018.18.2.26

53. Şenol, F. (2016) Türkiye Turizm Coğrafyası ve Dünya Kültürel Mirası, 5. Bask1, Ankara: Detay Yayıncilik.

54. Toksarı, M., Senir, G., \& Mürütsoy, M. (2015). Nostaljik içerikli reklam mesajlarının tüketicilerin satın alma davranışlarını etkileme düzeyi, Türkiye Sosyal Araștırmalar Dergisi, 19(3), 197-216.

55. Turgut, E., Akyol, A., \& Giray, S. (2016) Sosyal Medya Reklamlarında Tüketici Algılamaları İle Satın Alma Niyeti ve Ağızdan Ağıza İletişim Arasındaki İlişki, Journal of Life Economics, 3(2), 55-74. https://doi.org/10.15637/jlecon.123

56. Yıldız, S., \& Yıldız Z. (2015) Bilişim Teknolojilerinin Turizm Pazarlaması, Dağıtım mSistemi ve Seyahat Acentelerinin İş Modeli Değişimine Etkisi, Insan Ve Toplum Bilimleri Araştırmalar Dergisi, 4(3), 595-611. https://doi.org/10.15869/itobiad.30354

57. Yılmaz, V., \& Dalbudak, İ. Z. (2018). Aracı Değişken Etkisinin İncelenmesi: Yüksek Hızlı Tren İşletmeciliği Üzerine Bir Uygulama, Uluslararası Yönetim İktisat ve Issletme Dergisi, 14(2), 517-534.

58. Eser, Z. (2007) Nostaljinin Pazar Bölümleme Değisskeni Olarak Kullanılması Üzerine Kavramsal Bir Çalışma, Gazi Üniversitesi, Ticaret ve Turizm Fakültesi dergisi, Sayı:1, s.115-130.

59. Zeman, Z., \& Bogdan, A. (2019). Marketing strategy and building brand value on the Hungarian market, Ekonomicko-manazerske spektrum, 13(2), 1-9. https://doi.org/10.26552/ems.2019.2.1-9

60. Zhang, Z., Ye, Q., Law, R., \& Li, Y. (2010) The İmpact Of E-Word-Of-Mouth On The Online Popularity Of Restaurants: Acomparison Of Consumer Reviews And Editor Reviews, International Journal of Hospitality Management, 29,694-700. https://doi.org/10.1016/j.ijhm.2010.02.002 
Brief description of Author/Authors:

\section{Gönül GÖKER}

\section{Assistant Professor}

Ilgaz School of Tourism and Hotel Management, Çankırı Karatekin University, Turkey, gonulgoker@karatekin.edu.tr Research interests include tourism and hospitality management, tourism and gastronomy studies, recreation management studies.

\section{İlknur AYAR}

\section{Dr. Lecturer}

Vocational School, Çankırı Karatekin University, Turkey, ilknurkilic@karatekin.edu.tr, Research interests include marketing, consumer behavior, marketing for hospitality and tourism. 